УДК 78.071.2(71=161.2)

DOI:

Ірина Кліш, дочент кафедри народних музичних інструментів та вокалу Дрогобицького державного педагогічного університету імені Івана Франка

\title{
МИСТЕЦЬКА ДІЯЛЬНІСТЬ УКРАЇНСЬКОЇ ОПЕРНОЇ ТА КАМЕРНОЇ СПІВАЧКИ ІВАНКИ МИГАЛЬ (КАНАДА)
}

У статті розкривається мистецька діяльність украӥнської співачки Іванки Мигаль (мецио-сопрано), першої української солістки Метрополітен-опери в Нью-Йорку серед інших слов'ян, Канадської оперноі компанії. Подається опис ї̈ концертних виступів і оперних спектаклів, розкривається репертуар співачки $і$ значення ї̈ творчості в розвитку музичного мистечтва украӥнської діаспори другої половини ХХ ст.

До когорти видатних імен української діаспори, які досягли вершин слави у різних сферах діяльності, не маючи можливості повернутися на свою рідну землю, належить співачка Іванка Мигаль - вихованка Королівської музичної консерваторії в Торонто (клас солоспіву), оперної школи Торонтського університету (клас проф. Ернесто Вінчі), Літньої музичної школи в Аспені (США), студї Нью-Йоркської Метрополітен опери.

Ключові слова: Іванка Мигаль; співачка; кониертна практика; оперне мистецтво; гастролі; репертуар; музичне мистецтвво української діаспори.

Лim. 13.

Iryna Klish, Associate Professor of the Folk Musical Instruments and Vocal Singing Department Drohobych Ivan Franko State Pedagogical University

\section{ARTISTIC ACTIVITIES OF THE UKRAINIAN OPERA AND CHAMBER SINGER IVANKAMYHAL (CANADA)}

The article recounts the creative heritage of Ivanka Myhal, Ukrainian mezzo soprano singer who was the first Ukrainian solo singer at Met Opera in New York City among other Slavic artists of the Canadian Opera Company. The author provides a description of Ivanka Myhal's concert performances, opera productions, repertory, and also elaborates on the importance of her creative personality to the overall creative heritage of Ukrainian imigrants in the second half of the 20th century.

The coterie of renowned Ukrainian imigrants who have managed to excel in sundry realms of activity but were unable to return to their homeland includes Ivanka Myhal, alumnus of The Royal Conservatory of Music in Toronto (solo singing class), the Opera School of the University of Toronto (professor Ernesto Vinci's class), the Summer Music School in Aspen, Colorado, and of the New York Metropolitan Opera Workshop.

She started her career as a singer back in 1957 in Toronto as she was performing with the celebrated Leslie Bell Singers choir. She was a feature at numerous musical festivals across Canada and the States, and was also performing with symphonic orchestras in Toronto, Detroit, and Baltimore and in other places on the continent. On the 19th of January, 1970, Ivanka Myhal debuted in Die Zauberfl?te by Wolfgang Amadeus Mozart as a solo singer at New York Metropolitan Opera, having performed eleven parties in various opera performances. Wherever she was performing - be it in Stratford, Toronto, Minneapolis, Detroit, Thunder Bay, New York City, Chicago, Cleveland, Paris or elsewhere-the finale of each and every concert of hers featured a classical Ukrainian musical work - and she sang Ukrainian folk songs and romances as encore. Her repertory featured works by Mykola Lysenko, Semen Hulak-Artemovskiy, Kyrylo Stetsenko, Vasyl Barvinskiy, Yakiv Stepoviy, Andriy Hnatyshyn, Platon Mayboroda, Mykhaylo Verykivskiy, and other composers. In 1978, she recorded a vinyl disc of Ukrainian folk songs and romances at World Records studio. Ivanka Myhal made the top ten best singers worldwide. Her creative heritage inspires artists to create poetical and musical works and shall undoubtedly serve as a good example of dedication to one's native musical culture for the future generations of Ukrainian young people. diaspora.

Keywords: Ivanka Mygal; a singer; a concert; an opera art; touring; a repertoire; musical art of the Ukrainian

П остановка проблеми. Україна багата не тільки своїми відомими традиціями тазвичаями, архітектурними та сакральними спорудами, але ще й великими талантами. Нажаль, на протязі багатьох століть українці були змушені покидати свої рідні землі і шукати кращої долі чи й рятувати своє життя у чужинецькому краї. Своєю тяжкою працею вони досягали вершин слави у різних сферах діяльності, не маючи можливості повернутися на свою рідну землю.

Великі успіхи на чужомовних сценах не затьмарювали їх національних почуттів. Вони розвивали і пропагували українське мистецтво, 
активно виступали на українських емігрантських сценах з нагоди різних національних свят, в українських національних фестивалях, у програмах традиційних днів Українського Народного Союзу та ін. Служили добрим прикладом для молодого підростаючого покоління.

Мета статті полягає у розкритті ролі Іванки Мигаль в розвитку музичної культури України й української діаспори, зокрема в сфері вокального виконавства, аналізі їі творчої спадщини і громадської діяльності.

Огляд останніх досліджень і публікацій. Серед досліджень, присвячених аналізу мистецьких надбань співачки в Україні належить праця Івана Лисенка [10] і Л. Гарасимів [1], ii діяльність в діаспорі фрагментарно розкривають публікації Й. Гошуляка [3], Г. Карась [8], Г. Гораль і Л. Вовк [2], О. Стецик і Л. Вовк [13]. Важливими для відтворення творчих звершень співачки стали відгуки в пресі на їі концертні програми, зокрема в часописі “Свобода" (США).

Виклад основного матеріалу. Іванна Мигаль, оперна і концертна співачка, меццосопрано належить до когорти талановитих митців української діаспори. Народилася 6 липня 1937 року у Львові в родині вчителів. Батько, Григорій Мигаль, студіював на відділі скрипки музичної консерваторії у Львові, на вищому педагогічному курсі у Познані (Польща), в педагогічному інституті у Львові. Працював вчителем музики у початкових і середніх школах (1928 - 1934 рр.). Від 1939 року він заступник директора, а з 1942 року директор середньої комерційної школи. Мати, Марія-Стефанія $з$ дому Бойко, багато уваги приділяла музичній освіті доньки. Іванка, будучи маленькою, любила слухати віртуозну гру батька, засинати під спів маминої колискової “Ой ходить сон коло вікон".

У 1940 - 1947 роках Іванка була вже солісткою в дитячому хорі садочка сестер-служебниць. Дуже чисто інтонувала і легко запам'ятовувала мелодії пісень. Вже тоді сестри-служебниці звернули увагу на їі чарівний голос. Дитячі роки I. Мигаль минули в Бузьку, де вчителювали іiі батьки, тут Іванка вступила до першого класу [13].

Війна змінює життя людей і родина Мигалів змушена була залишити рідну землю. У 1944 році вони переїжджають до Німеччини і зупиняються у місті Ляндегут у таборі для інтернованих осіб. Тут Іванка починає навчання у початковій школі, закінчує три класи гімназії і бере приватні уроки гри на фортепіано.

У 1949 році родина Мигалів потрапляє до Канади у місто Тандер-Бей. На початках життя було дуже важким. Щоб не померти 3 голоду батько тачкою перевозив вугілля та пересушував на елеваторі збіжжя. Вечорами, будучи дуже втомленим, ішов співати до новоприбулих українців. Він організовував хори, колядував 3 однодумцями, а зароблені гроші перераховував на побудову Українського народного дому. Кожної суботи давав уроки музики і мови фермерським дітям. Мати Іванки працювала у пральні, а після важкої праці не мала змоги грати на фортепіано чи скрипці.

Ситуація трохи змінилася, коли Григорій Мигаль став диригентом змішаного хору при товаристві “Просвіта", де солісткою була Іванка. У 1955 році Мигаль організовує чоловічу хорову капелу імені Івана Франка. I в такому мистецькому середовищі зростала майбутня оперна співачка.

“Бог нагородив Іванку талантом. Батько і мати не дали його “закопати”. Своїм прикладом щодо працьовитості задля хліба насушного, на просвітницькій ниві в ім'я любові до свого рідного, українського виховали своє дитя - співучу золотоволоску" [5].

В Тандер-Беї Іванка почала систематично займатися музикою в місцевій музичній школі. Після двох років навчання, вона брала приватні лекції фортепіано і співу у відомої канадської піаністки М. Оулд. У 1957 році за їі рекомендацією Іванка вступила до Королівської музичної консерваторії в Торонто по класу солоспіву. Пізніше продовжувала навчання в оперній школі Торонтського університету у професора Ернесто Вінчі і закінчила його з відзнакою.

Ще студенткою Іванка Мигаль співала у церковному хорі УГК св. о. Миколая під керівництвом професора I. Ковалева, а співацьку кар'єру розпочала 1957 року в Торонто з відомим співацьким ансамблем “Леслі Белл Сінгерс". Одночасно співає в хорі, а потім і в малих ролях Канадської опери. По закінченні музичних студій у Торонтському університеті Іванка кілька літніх сезонів співала в опереті Джілберта і Салівана "Мікадо" на сцені театру в Стартфорді.

За порадою диригента Торонтського симфонічного оркестру В. Саскінда молода співачка переїхала до США і вступила до Літньої музичної школи в Аспені. Місто славилося різними фестивалями, у яких брали участь оперні виконавці світового рівня. Іванка Мигаль теж активно включилася до участі у цих фестивалях (1965-1976), виконуючиролів операхІ.Стравінського, Дж. Россіні, Р. Штрауса і В. А. Моцарта [8, 892]. Від 1964 року співачка виступала з сольними концертами у Страдфордському театрі, в оперній 
компанії Торонто, на радіо і телебаченні СВС. Цікавою для виконавиці була участь їі як солістки з 17-ти найкращими симфонічними оркестрами, 3 якими вона виконувала твори композиторів світової слави [8, 892].

Про концертну і репертуарну палітру співачки музикознавець I. Лисенко писав: “Виступала на музичних фестивалях у Канаді і США, а також із симфонічними оркестрами в Торонто, Детройті, Балтиморі та ін. Широко відома як пропагандистка української музики на американському континенті. У іiі репертуарі були твориС.Гулака-Артемовського,М. Лисенка,К. Стеценка, В. Барвінського, Вериківського та ін." [10, 364].

1967 року, після участі в конкурсі, Іванка Мигаль вступає на студію Нью-Йоркської Метрополітен опери, де ії зараховують до числа студійців і призначають стипендію Лукреції Борі, як для особливо перспективної виконавиці [5]. Тут вона вдосконалює свій голос, поповнює теоретичні знання, вивчає сценічний рух. Зі студією вона об'їздила всі великі міста США та Канади. Але вона дуже прагнула стати солісткою НьюЙоркської Метрополітен опери і у 1970 році ця мрія здійснилася.

"Голос Іванки Мигаль - це подих Метрополітенської величі. Виснажливою працею, без спонсорів і меценатів, без зв'язків і підтримки Іванка Мигаль пробилася у чужій країні до вершин слави, увійшла до першої десятки співаків світу. I в колекції рафінованих особистостей американської "Метрополітен-опера" наша землячка посідає заслужене місце” [5].

19 січня 1970 року, в день Святого Водохреща Іванка Мигаль дебютувала в опері В. А. Моцарта “Чарівна флейта", а 14 вересня 1970 року відкриття чергового сезону Метрополітен-опери відбулося виставою опери Д. Верді “Ернані”, у якій партію Джованни виконувала Іванна Мигаль $[6,1]$.

У наступному, 1971 році українські співакисолісти Метрополітен-опери Іванка Мигаль і Андрій Добрянський (бас) здійснили турне по США. І. Мигаль співала в “Мадам Батерфляй” (роль пані Пінкертон) в Міннеаполісі та Детройті [4,3].

В “Метрополітен-опера" Іванка Мигаль виконала одинадцять партій в таких операх як “Ернані”, “Мадам Батерфляй”, "Парсифаль”, “Ріголетто”, “Фауст”, “Тоска”, “Севільський цирульник”, “Луїза Міллер” та ін. 3 поміж багатьох ролей найбільш вдалою була головна роль в опері “Ведмідь” Вільяма Волтона за оповіданням А. Чехова. У 1975 році на новий рік оперу транслювали по телебаченню в усіх штатах. Це була вершина іiі мистецької кар'єри.
Іванка Мигаль була солісткою Канадських оперних компаній від 1974 року. На одному 3 вечорів, який організував Український визвольний фонд, про окрасу цього вечора розповіла газета “Новий шлях" від 6 травня 1972 року: “У мистецькій частині виступила співачка НьюЙоркської Метрополіталької опери, меццо-сопрано Іванка Мигаль 3 фортепіановим супроводом Зенка Лавришина і член канадської оперної компанії басбаритон Йосип Гошуляк у супроводі Тетяни Ткаченко, фортепіано" [3, 202].

Як співачці світового рівня, їй пропонували головні ролі в провідних оперних постановках і виступи в концертах із різними симфонічними оркестрами. Вона мала величезний успіх як на американському, так i на європейському континентах. Особливу увагу слід звернути на те, що успіхи на чужоземній сцені ніколи не затьмарювали їі національних почуттів. "Будучи студенткою, а потім і професійною співачкою, Іванка Мигаль радо виступала на різних українських сценах 3 нагоди важливих національних свят. Це відбувалося у Тандербей, Торонто, в Нью-Йорку, Чикаго та в Клівленді, де

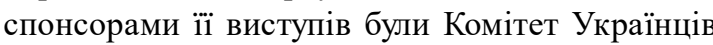
Канади та Український Комітет Америки" [13].

Про концерт солістки Метрополітен опери на традиційних Днях Українського Народного Союзу на Союзівці 18 вересня 1971 року газета “Свобода” писала: “Співачка Іванка Мигаль відспівала при фортепіяновому супроводі відомого українського піяніста Романа Стецури, в першій частині концерту три пісні: “Хотіла б я піснею стати” (К. Стеценка - І. К.), “Ой, поля, ви поля” (В. Барвінського - I. К.), й арію із “Запорожця за Дунаєм” п. н. “Ангел ночі над землею” (С. ГулакаАртемовського - I. К.) і в другій частині - дві українські пісні “На білу гречку впали роси” i "На вулиці скрипка грає” та одну із арій із “Севільського цирульника”. Бурхливо оплескувана за мистецьке виконання цих пісень співачка проспівала як наддаток одну із арій з опери “Кармен” $[9,1]$.

Особливо успішним був виступ І. Мигаль на святі Державності в Нью-Йорку 23 січня 1972 року. Газета “Свобода” писала: “Атракцією мистецької частини цього Свята буде виступ відомої співачки Метрополітальної Опери, меццосопрано Іванки Мигаль, при акомпаніяменті композитора Ігоря Соневицького" [7, 1]. Співачка виконала низку солоспівів К. Стеценка.

Разом 3 Ігорем Соневицьким (фортепіано) Іванка Мигаль брала участь у ювілейному концерті з нагоди 50-ліття Союзу Українок Америки, який відбувся 30 листопада 1974 року в Нью-Йорку [12, 7]. 
Де б вона не співала усі свої концерти закінчувала українською класикою, а на "біс" співала українські народні пісні та романси. В їі репертуарі були твори М. Лисенка, С. ГулакаАртемовського, К. Стеценка, В. Барвінського, Я. Степового, А. Гнатишина, П. Майбороди, Вериківського та ін. І. Мигаль була першою українською співачкою Метрополітен-опери серед інших слов'ян. Двічі побувала в СРСР і жодного разу не була на батьківській землі. Мріяла приїхати в Україну і виступити у Львові, де народилася, у Бузьку, де пройшли ії дитячі роки, на Сокальщині - батьківщині батьків.

Іванка Мигаль передчувала свій фізичний стан і хотіла залишити добрузгадку для своїх земляків. 3 цією метою у 1978 році вже будучи хворою, I. Мигаль виступила 3 українською програмою у Парижі й наспівала платівку українських народних пісень та романсів на студії World Records. Було записано п’ятнадцять творів українських композиторів-класиків у супроводі фортепіано, оркестру, бандури, чоловічого та жіночого хору. Це: “Ангел ночі (С. Гулак-Артемовський), “Ой поля, виполя" (муз. В.Барвінського, сл. О. Кониського), “Садок вишневий” (муз. М. Лисенка, сл. Т.Шевченка), "Пісня (муз. А. Гнатишина, сл. Гр. Чупринки) "На білу гречку впали роси" (муз. Б. Веселовського, сл. М.Рильського), "Вечірня пісня” (муз. К. Стеценка, сл. В. Саміленка), "На вулиці скрипка грає" (традиційна народна пісня, обробка-М. Красєва), "Хотіла б я піснею стати" (муз. К. Стеценка, сл. Л. Українки), "Кряче ворон” (муз. К. Стеценка, сл. С. Кротевича), “Стояла я і слухала весну” (муз. К. Стеценка, сл. Л. Українки), "Київський вальс" (муз. П. Китастого, сл. Л. Китастого), “Тихо гойдаються” (муз. та сл. С. Гулака-Артемовського), “Утоптала стежечку'(муз. Я.Степового, сл. Т.Шевченка), “Не шуми калинонько” (муз. І. Шамо, сл. Д. Луценка), “Ти моя вірна любов” (муз. П. Майбороди, сл. А. Малишка).

Та затяжна хвороба перервала їі мистецький злет. Після довготривалої боротьби з затяжною недугою 18 вересня 1983 року в місті Торонто у розквіті творчих сил перестало битися серце прекрасної української співачки Іванни Мигаль. Похована в місті Тандер-Бей (Онтаріо, Канада) на кладовищі св. Патрика поряд 3 могилою матері $[11,3]$.

Подаємо цікавий і промовистий спомин про I. Мигаль видатного українського співака, від 1954 року соліста Торонтської опери Йосипа Гошуляка (1922 - 2015). У 1957 році Іванка Мигаль була студенткою музичної консерваторії в Торонто і співала в хорі Святомиколаївської церкви. Йосип Гошуляк був членом церковної громади і як співак брав активну участь у церковно-громадських заходах. I ось тут він познайомився 3 новою співачкою хору. Він згадував: “Перед собою я побачив молоду, вродливу дівчину, ії зовнішність, статура нагадували мені відому італійську зірку Софію Лорен" [3, 490].

Так він довідався, що це була Іванка Мигаль співачка, меццо-сопрано. Протягом свого творчого життя Йосип Гошуляк зустрічався 3 Іванкою на репетиціях різних вистав Канадської опери, слідкував за їі творчим розвитком.

В листі до батька Іванки Мигаль - Григорія Мигаля - відомого громадського діяча, учителя, скрипаля, диригента, Йосип Гошуляк пише: “Мені хочеться згадати про одну дуже цінну рису Іванчиної особистості, яка чітко збереглася в моій пам'яті. Йдеться про її гордість за своє українське походження, йдеться про ії навіть демонстроване українське самоусвідомлення. Цю свою рису Іванка проявляла по-різному: на її власне бажання, а то й домагання, наші з нею розмови велися виключно рідною мовою, часто демонстраційно, навмисне в присутності англійськомовних колегспіваків. Одного разу до тих, хто з боку слухав нашу розмову, Іванка неначе жартома, але радше серйозно виголосила таку ось “промову": "Слухайте, слухайте мене, дорогі мої колеги. Нас тут поки що двоє українців, але ми не менш важливі за інших, ви це самі знаєте. А мова наша, українська, якою ми 3 паном Гошуляком часто розмовляємо, як самі чуєте, - співуча, мелодійна, прекрасна. Ви до неї прислухайтесь і вивчайте іï, співайте нею" [3, 491].

Не забули про видатну співачку і їі земляки з Буська, де пройшли ії дитячі роки. У краєзнавчому музеї при районному Народному домі та історикокраєзнавчому музеї Буської гімназії творчості Іванки Мигаль присвячена частина експозиції. На стіні Буської середньої школи № 2 встановлено меморіальну дошка, присвячену видатній співачці.

У 1999 році у Буську був проведений перший фестиваль авторської пісні “Ти до нас вертаєшся піснями”, присвячений І. Мигаль. Досить широко популяризував творчу спадщину Іванки Мигаль часопис "Воля народу" і Буське радіо, а журналістка Леся Котюк створила півгодинний документальний фільм про I. Мигаль [1].

У 2017 році в Буську теж урочисто відзначили 80-річчя від дня народження всесвітньо відомої оперної співачки. Звучали щирі слова визнання земляками великого таланту цієї жінки [2]. Ї̈̈ творчість надихає митців на створення поетичних та музичних творів. Ми - українці, повинні знати і гордитися талановитими співаками і митцями, які 
здобули вершини світової слави і до кінця залишилися вірними своїй рідній землі.

\section{ЛІТЕРАТУРА}

1. Гарасимів Л. Українське коріння канадського соловейка [Електронний ресурс] / Лариса Гарасимів // Режим доступу: http://leopolis.news/ ukrayinske-korinnya-kanadskogo-solovejka/

2. Гораль Г., Вовк Л. 80-річчя з дня народження всесвітньо відомої оперної співачки Іванки Мигаль відзначили уБуську [Електронний ресурс] / Г. Гораль, Л. Вовк // Режим доступу: http:// www.buskeradio.in.ua/80-richchya-z-dnyanarodzhennya-vsesvitno-vidomoyi-opernoyispivachki-ivanki-migal-vidznachili-u-busku/

3. Гошуляк Й. Й свого не цурайтесь. Спогади, листування, матеріали. - Львів: Каменяр, 1995. C. 202, 490-491.

4. Двоє українців співають в опері // Свобода. - 1971. - Ч. 84. - 6 травня. - С. 3.

5. Іванка Мигаль - видатна співачка. Серія матеріалів. [Електронний ресурс] // Режим доступу: https://buskfamouse.io.ua/s79787/ ivanka_migal_-_vidatna_spivachka

6. Іванка Мигаль виступала в опері, якою започатковано сезон // Свобода. - 1970. - Ч. 169. - 18 вересня. - С. 1.

7. Іванка Мигаль виступить на Святі Державности в Нью Йорку // Свобода. - 1972. - Ч. 10. - 18 січня. - С. 1.

8. Карась Г. Музична культура української діаспори у світовому часопросторі XX століття: монографія / Ганна Карась. - Івано-Франківськ: тіповіт, 2012. - С. 892.

9. Концерт із виступами Іванки Мигаль i ансамблю “Лиман” // Свобода. - 1971. - Ч. 174. -21 вересня. - С. 1.

10. Лисенко I. Співаки України (Мигаль І. Г.). Енциклопедичне видання. -К.: Знання. 2011.-С. 364.

11. Некролог: Іванка Мигаль // Свобода. 1983. - Ч. 191. - 7 жовтня. - С. 3.

12. Програма ювілейного концерту з нагоди 50ліття СУА // Свобода. - 1974. - Ч. 200. - 6 листопада. - С. 7.

13. Стецик О., Вовк Л. Іванка Мигаль - оперна солістка / Оксана Стецик, Леся Вовк [Електронний pecypc] // Режим доступу: https://buskfamouse.io.ua/ s79787/ivanka_migal___vidatna_spivachka

\section{REFERENCES}

1. Harasymiv, L. Ukrainske korinnia kanadskoho soloveika [Ukrainian roots Canadian Nightingale]. Available at: http://leopolis.news/ukrayinske-korinnyakanadskogo-solovejka/ [in Ukrainian].

2. Horal, H. \& Vovk, L. 80-richchia z dnia narodzhennia vsesvitno vidomoi opernoi spivachky Ivanky Myhal vidznachyly u Busku [80th anniversary of the birth of world-famous opera singer Ivanka Mygal noted in Busku]. Available at: http:/www.buskeradio.in.ua/80-richchya-z-dnyanarodzhennya-vsesvitno-vidomoyi-opernoyispivachki-ivanki-migal-vidznachili-u-busku/ [in Ukrainian].

3. Hoshuliak, Y. (1995). Y svoho ne tsuraites. Spohady, lystuvannia, materialy [And its beacon. Memoirs, correspondence, materials]. Lviv: Kameniar, pp. 202, 490-491. [in Ukrainian].

4. Dvoie ukraintsiv spivaiut v operi (1971). [Two Ukrainians sing in Opera]. Svoboda, part 84, p.3 [in Ukrainian].

5. Ivanka Myhal - vydatna spivachka. Seriia materialiv [Ivanka Mygal is an outstanding singer. Series of materials]. Available at: https:// buskfamouse.io.ua/s79787/ivanka_migal__vidatna_spivachka [in Ukrainian].

6. Ivanka Myhal vystupala v operi, yakoiu zapochatkovano sezon (1970). [Ivanka Mygal has performed in Opera, which started the season]. Svoboda, part. 169, p. 1. [in Ukrainian].

7. Ivanka Myhal vystupyt na Sviati Derzhavnosty v Niu Yorku (1972). [Ivanka Mygal will perform at Statehood in New York City]. Svoboda, part. 10, p. 1 [in Ukrainian].

8. Karas, H. (2012). Muzychna kultura ukrainskoi diaspory u svitovomu chasoprostori XX stolittia. Monohrafiia [Musical culture of the Ukrainian diaspora in the global of the twentieth century]. Ivano-Frankivsk: Tipovit, p. 892. [in Ukrainian].

9. Kontsert iz vystupamy Ivanky Myhal i ansambliu "Lyman" (1971). [Concert with performances by Ivanka Mygal and ensemble "Liman"]. Svoboda, part. 174, p. 1. [in Ukrainian].

10. Lysenko, I. (2011). Spivaky Ukrainy(Myhal I. H.). Entsyklopedychne vydannia [Lysenko I. Singers of Ukraine (Mygal I. H.). Encyclopedic Edition. Kyiv: Znannia, p. 364. [in Ukrainian].

11. Nekroloh: Ivanka Myhal (1983). [Obituary: Ivanka Myhal]. Svoboda, part. 191, p. 3. [in Ukrainian].

12. Prohrama yuvileinoho kontsertu $\mathrm{z}$ nahody 50 littia SUA (1974). [The program of the Jubilee concert with the occasion of the 50 anniversary of the CYA]. Svoboda, part 200, p. 7. [in Ukrainian].

13. Stetsyk, O., \& Vovk, L. Ivanka Myhal operna solistka [The Opera soloist Ivanka Mygal]. Available at: https://buskfamouse.io.ua/s79787/ ivanka_migal_-_vidatna_spivachka [in Ukrainian].

Стаття надійшла до редакції 08.06.2018 